\title{
CONTRIBUTION TO THE CHARACTERISTIC OF CLADIUM MARISCUS (L.) POHL POPULATION IN THE INITIAL ZONE OF FLOATING MAT ON AN OLIGO-HUMOTROPHIC LAKE IN NORTH-EASTERN POLAND
}

\author{
ANNA NAMURA-OCHALSKA \\ Department of Plant Ecology and Nature Protection \\ Institute of Botany, Warsaw University \\ Al. Ujazdowskie 4, 00-478 Warsaw, Poland \\ e-mail: namurka@biol.uw.edu.pl
}

(Received: August 16, 2004. Accepted: November 10, 2004)

\begin{abstract}
In the initial phase of growth in an oligo-humotrophic lake, Cladium mariscus forms a dense and tall sawgrass bed invading the open water in the form of a floating mat. High densities of submerged evergreen perennial stems of C. mariscus, over two metres high and abundantly fruiting, ensure its persistence, and form a natural barrier to the invasion of other species. Dense mats of sawgrass are formed as a result of clonal and rhizome growth. Although diaspore production is abundant under natural conditions, only vegetative propagation of stems was observed. In different variants of the experiment only seeds wintering on stems of mother plants were capable of germinating. Hard seed coats had an important effect on the germination capacity of seeds.
\end{abstract}

KEY WORDS: Cladium mariscus, population dynamics, spatial structure, clonal growth, diaspore production, seed germination capacity.

\section{INTRODUCTION}

Cladium mariscus (L.) Pohl, which in Poland has the eastern boundary of its continuous range, belongs to the group of old amphiancylusian relicts (Czubiński 1950). In Poland, it occurs mainly in the Pomeranian Lakeland (Jasnowski and Jankowska 1960; Jasnowski 1962; Kępczyński and Ceynowa 1968; Jasnowski et al. 1972), Wielkopolska region (Kaczmarek 1963; Denisiuk 1980; Żukowski and Jackowiak 1995), and in the Lublin region (Fijałkowski 1961; Buczek and Buczek 1993, 1996). Not so often and on fewer sites this species can be observed in north-eastern Poland, that is, in the Masurian Lakeland (Polakowski 1963, 1969; Solińska 1965; Kłosowski and Tomaszewicz 1979; Kłosowski 1986-1987, 1990).

A deep concern arises from the fact that both the number of $C$. mariscus sites and the size of the area occupied by this species are rapidly declining, especially in recent years (Borowiec 1990; Jasnowska and Jasnowski 1991; Żukowski and Jackowiak 1995; Buczek and Buczek 1993, 1996). The main reason is degradation of the natural habitat, mainly caused by lowering water table, drainage of wetlands, their management, and eutrophication of lakes. C. mariscus grows mainly in the marginal zone of mesotrophic lakes, less often in peatland. Its occurrence is thus limited to wet and marshy habitats, recently subjected to deep transformations, most often irreversible.

A valuable new site of $C$. mariscus was discovered in the Olsztyn Lakeland, north-eastern Poland, where this species occurs in the littoral zone of a small oligo-humotrophic lake without flow, located in Napiwodzko-Ramucka Forest, Nidzica forest division (Namura-Ochalska 2004). Lakes of this type, together with transition and raised bogs of the classes Scheuchzerio-Caricetea and Oxycocco-Sphagnetea developed during vegetation succession in lakes, recently belong to the category of biocoenoses subjected to the highest ecological threat. Few of them preserved their natural character, and they form a unique aquatic-peatland complex that differs from other vegetation types (Vasander et. al. 1988; IUCN, UNEP, WWF 1991; IUCN 1992; Spellerberg and Hardes 1992). Because of the extreme habitat conditions, especially unstable, soft and wet substrate with a low content of nutrients and rich in humus, the vegetation of these lakes has a specific structure and floral composition that develop during succession. This specific character of plant cover can be observed already in the initial phase of succession, when $C$. mariscus forms a floating mat on the surface of water.

The purpose of the study was an analysis of population properties and adaptations of $C$. mariscus to specific condi- 
tions of the floating mat developed during the initial phase of succession in a mid-forest, oligo-humotrophic lake without flow. The following variables were examined:

a) size of the occupied area,

b) number of individuals in the population,

c) density of vegetative and generative stems,

d) height of the aboveground stems,

e) forms of vegetative growth and length of the rhizome,

f) production of seeds and their germination capacity.

In addition, phytosociological site records were taken to classify the vegetation, and physico-chemical water analyses were performed to characterise site conditions.

\section{MATERIAL AND METHODS}

The field study was conducted in 2000-2003 in the zone of vegetation growth on the mid-forest humotrophic lake Zdręczno Małe. Geographical location of the new site of $C$. mariscus was determined by using the GPS (Global Position System) technique.

In the growing season of the first study year, 10 phytosociological site records were taken in homogeneous patches of the floating mat, using the Braun-Blanquet (1964) method. The records were set up in tables arranged with respect to characteristic species combinations according to the most recent phytosociological classification (Matuszkiewicz 2001). Moreover, the dominant species of the adjacent phytocoenoses were noted. The depth of the lake was measured in direct vicinity of the floating mat.

Based on the surface area of the mat and the mean density of stems, the total number of individuals in the C. mariscus population was estimated. Each rooted aboveground stem was considered as a population unit.

To estimate the density of $C$. mariscus population and the fraction of generative stems, all aboveground stems in various developmental stages were counted on 10 plots, each $0.5 \mathrm{~m}^{2}$ in size, during four growing seasons. Also the percentage cover of $C$. mariscus was assessed on each plot.

To estimate the height of individuals in successive study years, the height of 100 randomly selected vegetative and generative individuals was measured. The measurements were taken from the submerged part of the mat to the tip of longest leave or fruiting stem. In addition, the depth of submerged parts of $C$. mariscus stems was measured.

Differences between means were tested by t-test at $\mathrm{p}=0.05$.

To examine the structure of individuals and their form of growth, five monolithes with a side length of $0.5 \mathrm{~m}$ each were taken from the mat invading the surface of water, from which polycorms of $C$. mariscus were isolated. Then, aboveground and underground stems of single individuals were counted, and distances between them were measured, along with the total length of the rhizome.

To estimate seed production per generative stem, 10 fruiting stems were randomly selected at the end of the growing season of 2000. All fully grown seeds were counted on each stem. Based on the mean density of generative stems and mean seed production per stem, seed production was estimated per square metre of the floating mat.

To evaluate germination capacity and timing, C. mariscus seeds were collected in October 2000 and subjected to the following treatments: a) freezing at $-10^{\circ} \mathrm{C}$,

b) cooling at $+4^{\circ} \mathrm{C}$,

c) drying at $+35^{\circ} \mathrm{C}$,

d) submerging,

e) removing seed coat.

Seeds were stratified and dried for one month, or submerged for a week. In each variant, 50 seeds were sown on Petri dishes lined with filter paper, in three replicates. Also three variants of substrate were used: besides filtrate paper, also peat soil mixed with sand in proportion 1:1 and $C$. $m a-$ riscus peat taken from its natural site. Moreover, seeds were sown in the dark. In the spring of 2001, seeds hibernating under natural conditions on mother stems were collected to examine their germination capacity when sown on filter paper, with the coat removed and not removed. All experiments were conducted in a Sanyo germinator MLR350 under constant humidity of $70 \%$, at $32^{\circ} \mathrm{C}$ for $8 \mathrm{hrs} \mathrm{du}-$ ring the day and at $22^{\circ} \mathrm{C}$ for $6 \mathrm{hrs}$ at night.

Basic statistics such as means, standard deviations and coefficients of variation were calculated for all variables. Tests t or chi-square for independent samples were used to evaluate the significance of differences. The difference was considered to be significant at the 0.05 level.

To characterise site conditions, soil samples were taken from Lake Zdręczno Małe. The chemical analysis of water comprised:

a) water reaction by using $\mathrm{pH}-$ meter $\mathrm{N}-122$,

b) colour - colorimetric method with platinum-cobalt gauge,

c) carbonate hardness and total hardness - titrimetric method with sodium mixture, electric conduction - conductometer OK. 102/1,

d) permanganate value - permanganate method in acid medium,

e) ammonia nitrogen - Nessler method,

f) nitrates - colorimetric method with phenoldisulfonic acid,

g) phosphates - colorimetric method with ammonium molybdate,

h) chlorides - Mohr method,

i) sulfates - nephelometric analysis,

j) sodium, potassium, calcium - flame photometer,

k) magnesium - atomic absorption spectrometer (ASA method),

1) iron - colorimetric method with ammonium rhodanate.

\section{RESULTS}

The new site of $C$. mariscus in the littoral zone of the oligo-humotrophic lake Zdręczno Małe $\left(20^{\circ} 29^{\prime} 73^{\prime \prime} \mathrm{E}\right.$ and $53^{\circ} 28^{\prime} 87^{\prime}$ 'N) covered an area of over $450 \mathrm{~m}^{2}$. In the initial phase of growth, $C$. mariscus formed a sawgrass bed invading open water in the form of a floating mat (Cladietum marisci) submerged to a depth of $10-30 \mathrm{~cm}$, and forming a belt of about 0.5 to $4.0 \mathrm{~m}$ wide that surrounds almost the whole lake. The floating mat represented a typical sawgrass bed (Cladietum marisci typicum), dense and poor in species (Table 1). The typical physiognomy of this community was due to the highly dominant characteristic species $C$. mariscus that reached a coverage of the 5th degree of the Braun-Blanquet scale, and a height of more than 2 $\mathrm{m}$. In the lower layer only Thelypteris palustris reached the 
TABLE 1. Cladietum marisci (All. 1922) Zobrist 1935 - variant typical of the inshore zone of lake Zdręczno Małe.

\begin{tabular}{|c|c|c|c|c|c|c|c|c|c|c|}
\hline \multirow{2}{*}{$\frac{\text { Date }}{\text { Running number }}$} & \multicolumn{10}{|c|}{ 2001-08-01 } \\
\hline & 1 & 2 & 3 & 4 & 5 & 6 & 7 & 8 & 9 & 10 \\
\hline Releve number & 2 & 9 & 1 & 7 & 3 & 10 & 4 & 5 & 6 & 8 \\
\hline Cover of c $(\%)$ & 95 & 100 & 100 & 100 & 100 & 100 & 100 & 100 & 100 & 100 \\
\hline Cover of d (\%) & 5 & & & & & 5 & 5 & & & \\
\hline Area in sq. $\mathrm{m}$ & 4 & 4 & 4 & 4 & 4 & 4 & 4 & 4 & 2 & 2 \\
\hline Number of species in the record & 13 & 9 & 8 & 8 & 6 & 5 & 4 & 3 & 3 & 3 \\
\hline \multicolumn{11}{|l|}{ ChAss. Cladietum marisci } \\
\hline Cladium mariscus & 5 & 5 & 5 & 5 & 5 & 5 & 5 & 5 & 5 & 5 \\
\hline \multicolumn{11}{|l|}{ ChCl., All.: Phragmitetea, Magnocaricion* } \\
\hline Carex appropinquata ${ }^{*}$ & 1 & 1 & & & 1 & & 1 & & & \\
\hline Scutellaria galericulata* & 1 & 1 & + & & & & & & & \\
\hline Carex elata* & & 1 & & 1 & & & & & 1 & \\
\hline Lysimachia thyrsiflora* & 1 & & & & & & & 1 & & \\
\hline \multicolumn{11}{|l|}{ Typha latifolia. } \\
\hline Thelypteris palustris & 3 & 2 & 3 & 2 & 1 & 2 & 1 & 2 & 2 & 2 \\
\hline Menyanthes trifoliata & 1 & 1 & + & & 2 & & 1 & & & \\
\hline Comarum palustre & + & & + & & & & & & & \\
\hline \multicolumn{11}{|l|}{ Companion species } \\
\hline Carex lasiocarpa & 1 & 1 & & 1 & & 1 & & & & + \\
\hline Pleurozium schreberi $\mathrm{d}$ & 2 & & 1 & 2 & 1 & & & & & \\
\hline Lysimachia vulgaris & 1 & 1 & & & 1 & 1 & & & & \\
\hline Calliergon cordifolium $\mathrm{d}$ & & & + & + & & & & & & \\
\hline Alnus glutinosa c & 1 & & 1 & & & & & & & \\
\hline Salix cinerea $\mathrm{c}$ & & & & 2 & & & & & & \\
\hline Viola palustris & + & & & & & & & & & \\
\hline Lycopus europaeus & + & & & & & & & & & \\
\hline
\end{tabular}

Vth degree of constancy, covering even $40 \%$ of the area (Table 1). On the land side there occasionally appeared species characteristic and differential of the alliance Magnocaricion, such as Carex appropinquata, Scutellaria galericulata, Carex elata, Lysimachia thyrsiflora, Thelypteris palustris, Menyanthes trifoliata, Carex lasiocarpa, Alnus glutinosa, Comarum palustre, Salix cinerea. Characteristic of Cladietum marisci typicum was the absence of the moss layer. Only Pleurozium schreberi was noted on emerged parts of plants, most often on the rhizome of $M$. trifoliata and T. palustris. Some patches of phytocoenoses were shaded by adjacent Alnus glutinosa and Salix cinerea. The depth of the lake in close vicinity to the floating mat was over $2 \mathrm{~m}$. On the side of the land, the zone of $C$. mariscus bordered on communities of the alliances Rhynchosporion albae and Magnocarcion.

At the beginning of the study, the total number of individuals in the $C$. mariscus population occupying the littoral zone of lake Zdręczno Małe was over 21000 emergent stems.

Population densities were very high during the four successive study years, and the differences in number of stems between the growing seasons were low, varying between about 25 and 31 per $0.5 \mathrm{~m}^{2}$ (Table 2). On each plot, C. $m a-$ riscus stems covered almost $100 \%$ of the area. Also variation in the proportion of generative stems was low, ranging from $25.5 \%$ to about $32 \%$ of all stems in successive years (Table 2). No seedlings of $C$. mariscus were found under natural conditions.

Fruiting stems reached a height of about $2 \mathrm{~m}$. Dry generative stems of the previous year were almost $0.5 \mathrm{~m}$ higher than those of the current year. In each growing season, the longest leaves of vegetative stems reached as many as over $2.17 \mathrm{~m}$ in 2003 to $2.64 \mathrm{~m}$ in 2001 (Table 2).

The analysis of the structure $C$. mariscus polycorms showed that individuals characteristic ability to two different types of clonal growth: guerilla and phalanx growth (Fig. 1). First, new shoots sprouted at the base of a massive aboveground stem and formed a tuft of shoot. Young fragments of polycorms consisted of only two, at most three, vegetative shoots, whereas old large tufts could contain even 12 large aboveground shoots, of which 30\% represented dead generative shoots of the previous year. Tufts sent out rhizomes in any direction, covered with scale-like leaves, that did not branch, and produced new aboveground shoots. The greater the number of aboveground shoots in a clone, the higher was the proportion of creeping rhizomes. Large $C$. mariscus tufts could grow even 18 rhizomes

TABLE 2. Characteristic of the Cladium mariscus population in the zone of plant invasion in oligo-humotrophic lake in successive years (mean value).

\begin{tabular}{lccc}
\hline Properties/years & 2000 & 2001 & 2002 \\
\hline Vegetative shoots density & $18.7 \pm 3.53$ & $22.7 \pm 4.03$ & $20.0 \pm 3.81$ \\
Generative shoots density & $7.9 \pm 2.56$ & $7.7 \pm 2.31$ & $9.7 \pm 1.34$ \\
Total shoots density & $26.6 \pm 5.50$ & $30.2 \pm 4.94$ & $30.7 \pm 4.55$ \\
Properties of generative shoots $(\%)$ & 29.7 & 25.5 & 31.6 \\
The length of the longest leaf on vegetative shoots $(\mathrm{cm})$ & $239.1 \pm 50.26$ & $263.7 \pm 39.87$ & $238.5 \pm 61.03$ \\
Generative shoots length $(\mathrm{cm})$ & $207.3 \pm 29.94$ & $196.7 \pm 39.28$ & $201.2 \pm 42.17$ \\
Last year's shoots length $(\mathrm{cm})$ & no data & $242.2 \pm 48.25$ & $217.5 \pm 68.92$ \\
\hline
\end{tabular}




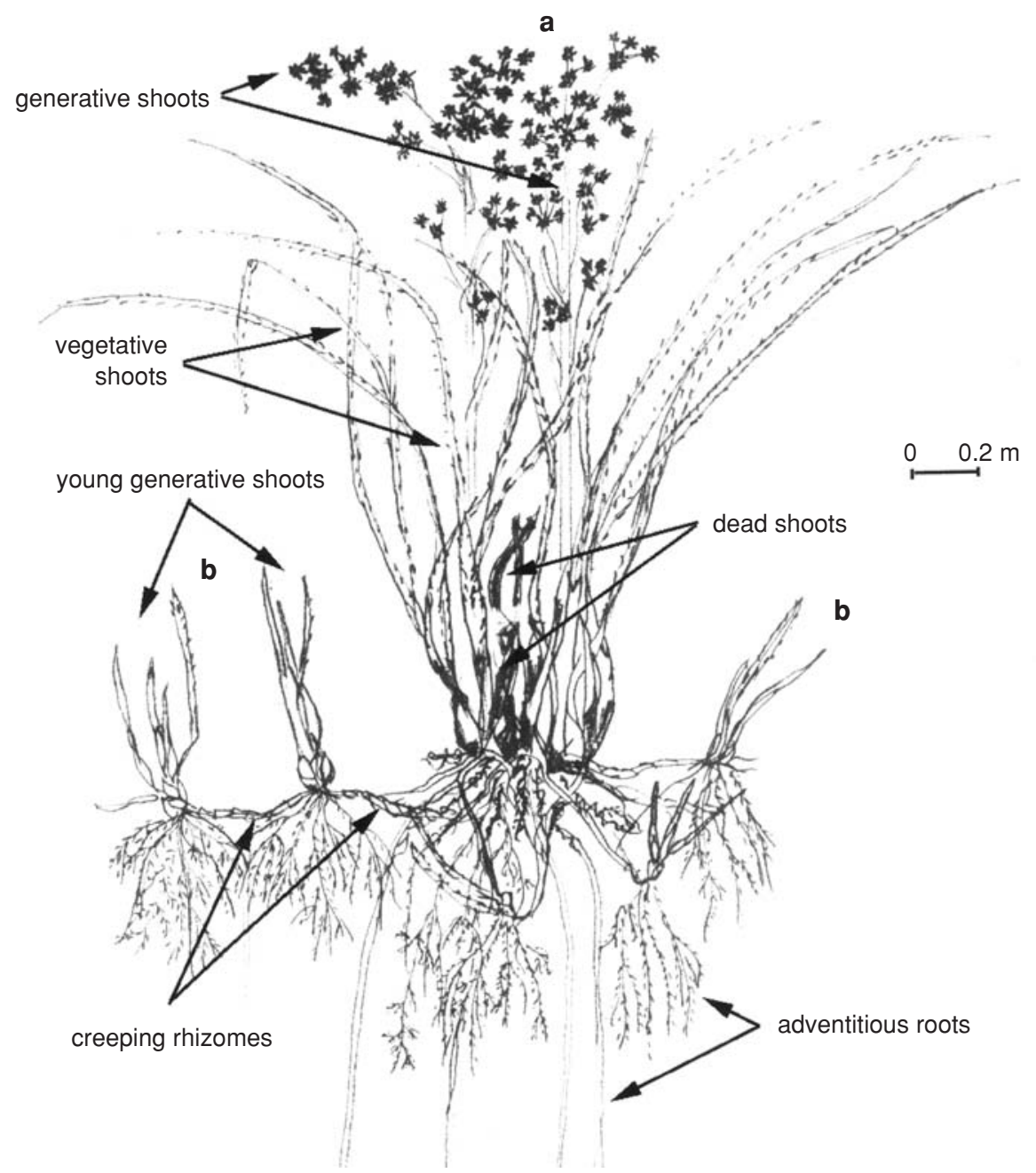

Fig. 1. Phalanx (a) and querilla (b) of clonal growth of Cladium mariscus. Creeping rhizomes, adventitious roots, dead stems, young generative shoots.

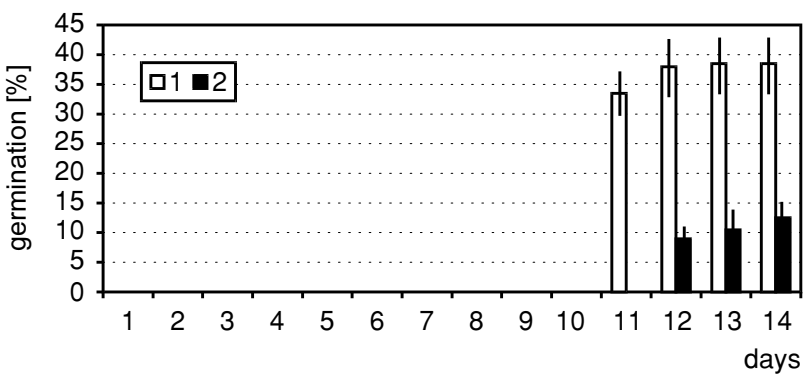

Fig. 2. Germination of Cladium mariscus seeds wintering on the mother plant. Seeds with coat removed (1) and not removed (2). Seeds of the current year did not germinate at all.

measuring from 7 to $35 \mathrm{~cm}$ in length. Typically, new aboveground shoots were formed at a distance of about $20 \mathrm{~cm}$ from the tuft. All rhizomes, except for short ones in early stages of growth, produced new aboveground shoots. Thus, new aboveground shoots grew at the bases of old shoots phalanx growth, as well as at some distance from them querilla growth (Fig. 1). A characteristic feature of the structure of polycorms was an abundant growth of adventitious roots with few or many branches, especially at the base of aboveground stems.

Mean seed production per generative stem was 1947.22 \pm 400.60 . It showed a high variation from about 1400 to 2734 , that is, by a factor of 2 . The estimated seed production per $1 \mathrm{~m}^{2}$ of the floating mat was as high as 30000 .
Germination capacity of $C$. mariscus seeds was interesting. Although they were produced in large quantities under natural conditions, only the seeds wintering on mother plants germinated in all variants of the experiment. In addition, the removal of hard coat markedly influenced their germination capacity. A highest germination capacity of $38 \%$ was observed in seeds with the coat removed, whereas the germination capacity of seeds collected at the same time but with coat not removed was reduced to one-third (Fig. 2). First sprouts emerged 11-12 days after sowing, and the whole process took merely 3-4 days. For the following three months no new sprout emerged, and the seeds were attacked by fungi.

The results of laboratory experiments showed that seeds of the current year could not germinate. No one seed germinated, independent of the substrate and light conditions, or special treatments such as stratification, drying, submerging, and coat removal.

The water of lake Zdręczno Małe was characterised by a neutral reaction $(\mathrm{pH}=7.2)$, yellowish-brownish colour $\left(44.5 \mathrm{mg} \mathrm{Pt} / \mathrm{dm}^{3}\right)$, very low total hardness $\left(1.8 \mathrm{mval} / \mathrm{dm}^{3}\right)$ and carbonate hardness $\left(1.6 \mathrm{mval} / \mathrm{dcm}^{3}\right)$, rather weak electrolytic conductivity $(134 \mu \mathrm{S})$, and increased permanganate value (18 $\mathrm{mg} \mathrm{O}_{2} / \mathrm{l}$ of water) (Table 3 ). Chemical analyses showed a very low content of nutrients, especially nitrates and phosphates, which was of the order of one-hundred or one-thousand parts of milligram per litre of water $(\mathrm{mg} /$ $\mathrm{dm}^{3}$ ). Also small amounts of ammonia nitrogen, chlorides, 
TABLE 3. Physical and chemical properties of water from lakes Zdręczno Małe.

\begin{tabular}{|c|c|}
\hline Properties & Mean value \\
\hline $\mathrm{pH}$ & 7.2 \\
\hline Colour (mg Pt/dm³) & 44.5 \\
\hline Oxidability $\left(\mathrm{mg} \mathrm{O}_{2} / \mathrm{dm}^{3}\right)$ & 18.0 \\
\hline Electrolytic conductivity $(\mu S)$ & 134.0 \\
\hline Total hardness $\left(\mathrm{mval} / \mathrm{dm}^{3}\right)$ & 1.8 \\
\hline Carbonate hardness $\left(\mathrm{mval} / \mathrm{dm}^{3}\right)$ & 1.6 \\
\hline Total N (mg N/dm $\left.{ }^{3}\right)$ & 6.61 \\
\hline $\mathrm{NNH}_{4}\left(\mathrm{mg} \mathrm{NH}_{4}^{+} / \mathrm{dm}^{3}\right)$ & 0.18 \\
\hline $\mathrm{NNO}_{3}\left(\mathrm{mg} \mathrm{NO}_{3}^{-} / \mathrm{dm}^{3}\right)$ & 0.038 \\
\hline $\mathrm{NNO}_{2}\left(\mathrm{mg} \mathrm{NO}_{2}^{-} / \mathrm{dm}^{3}\right)$ & 0.00 \\
\hline $\mathrm{Fe}\left(\mathrm{mg} \mathrm{Fe} / \mathrm{dm}^{3}\right)$ & 0.02 \\
\hline $\mathrm{Cl}\left(\mathrm{mg} \mathrm{Cl} / \mathrm{dm}^{3}\right)$ & 1.86 \\
\hline $\mathrm{Ca}\left(\mathrm{mg} \mathrm{Ca} / \mathrm{dm}^{3}\right)$ & 9.6 \\
\hline $\mathrm{Mg}\left(\mathrm{mg} \mathrm{Mg} / \mathrm{dm}^{3}\right)$ & 2.43 \\
\hline $\mathrm{Na}\left(\mathrm{mg} \mathrm{Na} / \mathrm{dm}^{3}\right)$ & 1.68 \\
\hline $\mathrm{K}\left(\mathrm{mg} \mathrm{K} / \mathrm{dm}^{3}\right)$ & 0.68 \\
\hline $\mathrm{SSO}_{4}\left(\mathrm{mg} \mathrm{SO}_{4}^{-} / \mathrm{dm}^{3}\right)$ & 4.32 \\
\hline $\mathrm{PPO}_{4}$ total $\left(\mathrm{mg} \mathrm{PO}_{4}^{-3} / \mathrm{dm}^{3}\right)$ & 0.007 \\
\hline
\end{tabular}

iron, nitrogen, potassium, magnesium, and calcium were noted. Only total nitrogen was relatively high.

\section{DISCUSSION}

The new C. mariscus site is situated in the littoral zone of a mid-forest, small lake without flow, called Zdreczno Małe, where it forms partly a submerged floating mat spreading out on the open water as a dense and tall sawgrass bed. The high content of poorly soluble humus and low content of nutrients classify this lake to the group of oligohumotrophic bodies of water. The high content of organic matter is indicated first of all by yellowish-brown colour of water, increased permanganate value, and high total nitrogen. Weak electrolytic conductivity, low total and carbonate hardness, also low contents of cations and anions indicate that mineral compounds available to plants, in particular nitrates and phosphates, are scarce (Dojlido 1995). Neutral water reaction seems to be atypical to oligo-humotrophic lakes which are acid as a rule. There are many indications that $\mathrm{pH}$ values largely depend on the chemical composition of plant material, that is, on the species growing in lakes and forming sediments (Mikulski 1982). Sediments of peatmoss are always acid, whereas sedges and other plant species can produce even an alkaline reaction. Thus, a high proportion of $C$. mariscus and the absence of Sphagnum sp. in the littoral zone of the lake could account for the neutral water reaction.

Important factors determining individual growth and development, and population persistence include its size, that is, the area occupied and the number of individuals. Many studies have shown that small populations are more prone to extinction than abundant populations occupying large areas (Gray et al. 1987; Grubb 1987, 1988; Falińska 1997; Begon et al. 1999). Although the population of $C$. mariscus in the zone of invasion in lake Zdręczno Małe does not cover a large area, especially as compared with sawgrass beds covering several hundred hectares, for example, in north-western and central-eastern Poland, as described by Fijałkowski (1961), Jasnowski (1962), Kępczyński and Ceynowa (1968), Jasnowski et al. (1972), Buczek and Buczek
(1993), it is characterised by a very high density of submerged, tall, well grown and abundantly fruiting individuals, covering nearly $100 \%$ of the area.

Temporal and spatial persistence of the population is also influenced by the size of individuals and the way of area occupancy (Schmid and Harper 1985; Schmid and Bazzaz 1987; Silvertown 1987; Weiner 1999). C. mariscus is one of the most luxuriant perennials in our flora. Densely 'packed' per unit area, partly submerged, massive, perennial and evergreen individuals with many shoots reaching a height of over $2 \mathrm{~m}$, totally fill the empty space, forming an effective natural barrier to invasion of other species, even from adjacent bog communities. This new population seems to be less liable to extinction than populations covering large areas but with low stem density. Only in less inundated patches, with more solid substrate, the proportion of other species was higher, especially that of Thelypteris palustris covering about $40 \%$ of the lower herb layer. Due to numerous adaptations, including an abundant system of aquatic roots, this species can survive prolonged inundation, though the optimum of its occurrence is in adjacent communities of Thelypteridi-Phragmitetum. The high proportion of $T$. palustris in phytocoenoses of Cladietum marisci thus provides evidence for the lowering of water level and invasion of other species (Solińska 1965; Polakowski 1969; Staniewska-Zątek 1977). These site-floristic changes have not been confirmed by Kłosowski (8687 ), who found that $T$. palustris typically occurred in deeply inundated patches.

Nearly single-species phytocoenoses, with at most a low proportion of other species, are rare under natural conditions. Typically, they occur under extreme conditions, or as ephemeral populations invading new areas (Gray et al. 1987; Falińska 1991; Begon et al. 1999). Among characteristic features of $C$. mariscus is its ability to invade the surface of water by forming a floating mat that is expanding towards the centre of the lake.

Dense stands of sawgrass are produced as a result of vegetative growth of polycorms. Polycorms of $C$. mariscus have two forms of clonal growth: phalanx - in tufts with very short rhizomes and several to several dozen aboveground stems growing close to each other, and querilla - by creeping rhizomes producing shoots sprouting at a distance of about $20 \mathrm{~cm}$ from the tuft. Phalanx growth results in a high density of shoots without expending energy for the growth of long rhizomes, whereas the querilla growth determines invasion to new areas, uptake of nutrients and their storage in rhizomes. Chlewińska-Karpowiczowa (1929) has found that the rhizomes of $C$. mariscus contain much starch in autumn, whereas only single portions in spring. $C$. mariscus polycorms/clones also have two kinds of well developed systems of adventitious roots. These are so called "aquatic" roots, with many branches and root hairs that take water and nutrients, and long, not branching roots that anchor the plant in the ground. Thus, the ability of individuals to propagate by querilla and phalanx of clonal growth, well developed system of rhizomes and roots, and high activity of dormant buds ensure anchorage and intensive growth and restoration of clones forming the floating mat. Many studies documented positive effects of the size of individuals and vegetative growth on survival and competitive abilities (Harper 1977, 1980; Grime 1979; Jackson et al. 1985; Tilman 1987, 1988). As a consequence of ad- 
aptations typical of aquatic plants, especially well developed aeration and mechanical tissues, $C$. mariscus tolerates inundation of aboveground shoots even to a depth of over $30 \mathrm{~cm}$. Systems of large air spaces with carbon dioxide and oxygen occur in all parts of the plant from leaves to underground organs, and guarantee resistance even to a permanent inundation (Chlewińska-Karpowiczowa 1929). According to Podbielkowski and Tomaszewicz (1996), they contribute to $38 \%$ of the rhizome volume, $60 \%$ of the root volume, and $65 \%$ of the leaf bases. Well developed mechanical tissue with a high content of silica enables orthotropic structure of aboveground stems, resistant to wind and bending, and bearing heavy fruits at a considerable height. Moreover, thick and stiff leaves, with a high content of silica, and sharp, hooked teeth on the margins are not grazed by herbivores, and effectively protect from intrusion by humans and animals.

Despite abundant production of large seeds, as many as 30000 per square metre, no seedlings and juvenile individuals were found under natural conditions. A rapid decline in the sprouting of deeply inundated sawgrass seeds was confirmed by Ponzio et al. (1995).

C. mariscus seeds form a bank of seeds wintering on generative stems of mother plants, which is an interesting adaptation to extreme and unpredictable habitat conditions. Only seeds that survived winter under natural conditions were capable of sprouting. Lack of germination in seeds collected in the autumn of the growing season in which they were produced, observed in different variants of the experiment. The state of deep dormancy enables survival of adverse environmental conditions, increasing the chance of seed sprouting and, at the same time, preventing the sprouting of all seeds ,here and now” (Grzesiuk and Kulka 1981; Grubb 1987; Symonides 1989; Eriksson 1995; Tobolski 2000).

Sprouting of $C$. mariscus seeds largely depends on the presence of hard seed coats. Their removal does not interrupt the state of dormancy in seeds of the current year, but it increases the capacity of germination by a factor of three in seeds wintering on generative stems. It is known from literature that the capacity and timing of the germination of seeds and their lifespan largely depend on the properties of their coat. In general, thin and permeable coats enable fast sprouting but they do not guarantee long survival of seeds, whereas thick and impermeable coats of hard seeds are the main cause of their dormancy (Grzesiuk and Kulka 1981). Thus, seeds with coat removed and wintering on mother plants had a highest germination capacity of 38\%. Seed bank, both wintering on generative stems and on peat, is an important component of reproductive strategy, especially under extreme habitat conditions. Tobolski (1987) has found that $C$. mariscus seeds often occur, sometimes in large amounts, in deposits of sawgrass peat. According to Chlewińska-Karpowiczowa (1929), a very low percentage of seeds ripens beyond the long period of dormancy. It should be noted, however, that she examined germination capacity of the seeds of the current year, among which only three out of several thousand germinated after 10 months.

To sum up, C. mariscus belongs to terrestrial-aquatic immersion plants with a high degree of specialisation. It has many adaptations to extreme conditions, even during permanent inundation on soft, unstable organic substrate saturated with water, poor in nutrients.

\section{LITERATURE CITED}

BEGON M., MORTIMER M., THOMPSON D.J. 1999. Ekologia populacji. Studium porównawcze zwierząt i roślin. [Population Ecology. A Unified Study of Animals and Plants]. PWN, Warszawa, pp. 362. (in Polish translation from English)

BOROWIEC J. 1990. Torfowiska Regionu Lubelskiego. PWN, Warszawa. (in Polish)

BRAUN-BLANQUET J. 1964. Pflanzensoziologie. Springer, Wien-New York, pp. 865.

BUCZEK A., BUCZEK T. 1996. Chełmskie torfowiska węglanowe. Fundacja IUCN Poland, Warszawa. (in Polish)

BUCZEK T., BUCZEK A. 1993. Torfowiska węglanowe w okolicach Chełma - walory przyrodnicze, zagrożenia, ochrona. [Carbonate marshes near Chełm - natural values, threats and protection]. Chrońmy Przyr. Ojcz. 49, 3: 76-89. (in Polish with English summary)

CHLEWIŃSKA-KARPOWICZOWA L. 1929. Cladium Mariscus R. Br., Studium ekologiczne. Arch. Nauk. Biol., T.N.W. 2 (4): 1-63. (in Polish)

CZUBIŃSKI Z. 1950. Zagadnienia geobotaniczne Pomorza. Bad. Fizjogr. nad Polską Zach. [Geobotanical Problems in Pomerania]. 2 (4): 437-658. (in Polish with English summary)

DENISIUK Z. 1980. Łąki turzycowe Wielkopolski (Klasa $P$ hragmitetea). [Sedge Meadows of the Wielkopolska Region (Phragmitetea Class]. Zakł. Ochr. Przyr. i Zasob. Natur. PAN. Studia Nat., Ser. A. 20: 1-140. (in Polish with English summary)

DOJLIDO J.R. 1995. Chemia wód powierzchniowych. Wyd. Ekonomia i Środowissko. Białystok, pp. 342. (in Polish)

ERIKSSON O. 1995. Seedling recruitment in deciduous forest herbs: the effects of litter, soil chemistry and seed bank. Flora, 190: 65-70.

FALIŃSKA K. 1991. Plant demography in vegetation succession. Kluwer Academic Publishers, Dordrecht, Boston, London, pp. 210.

FALIŃSKA K. 1997. Ekologia roślin. PWN. Warszawa, pp. 256. (in Polish)

FIJAŁKOWSKI D. 1961. Kłoć wiechowata Cladium mariscus (L.) Pohl. w województwie lubelskim. [Cladium mariscus (L.) Pohl. B lublinijskom wojewodstwie]. [Binsen-Schneide Cladium mariscus (L.) Pohl.in der Wojewodschaft Lublin]. Ann. UMCS. Sec. C. 14: 343-357. (in Polish with Russian and German summary)

GRAY A.J., GRAWLEY M.J., EDWARDS P.J. 1987. Colonization, succession and stability. Blackwell Sci. Publ., London.

GRIME J.P. 1979. Plant Strategies and vegetation processes. Wiley J. and Sons, Chichester, New York, Brisbane, Toronto.

GRUBB P.J., 1987. Some generalizing ideas about colonization and succession in green plants and fungi. In: Colonization, succession and stability. Gray A.J., Crawley M.J., Edwards P.J. (eds), Blackwell Scientific, Oxford, 81-102.

GRUBB P.J. 1988. The uncoupling of disturbance and recruitment, two kinds of seed bank, and persistence of plant populations at the regional and local scales. Ann. Zool. Fenn. 25: 23-32 .

GRZESIUK S., KULKA K. 1981. Fizjologia i biochemia nasion. PWRiL, Warszawa, pp. 606. (in Polish)

HARPER J.L. 1977. Population Biology of Plants. Academic Press, London, New York.

HARPER J.L. 1980. Plant demography and ecological theory. Oikos 35: 244-254.

IUCN 1992. Global biodiversity 1992. Status of the Earth's living resources.

IUCN, UNEP, WWF 1991. Caring for the Earth. A strategy for sustainable living - Gland.

JACKSON J.B.C., BUSS L.W., COOK R.E. 1985. Population Biology and Evolution of clonal organisms. Yale Univ. Press, New Haven and London, pp. 530. 
JASNOWSKA J., JASNOWSKI M. 1991. Dynamika rozwojowa roślinności torfotwórczej w rezerwacie „Kłocie Ostrowickie” cz. I. Szara roślinna torfowiska. [The Dynamic of the PeatForming Vegetation in Nature Reserve „Kłocie Ostrowickie” Part I. The Vegetation of Peatland]. Zesz. Nauk. Akad. Rol. Szczec., Rolnictwo LI, 149: 11-24. (in Polish with English summary)

JASNOWSKI M. 1962. Budowa i roślinność torfowisk Pomorza Szczecińskiego. Szczec. Tow. Nauk. Wydz. Nauk Rol.-Przyr. 10: 1-339. (in Polish with German summary)

JASNOWSKI M., JASNOWSKA J. 1960. Roślinność kalcifilna nad jeziorem Tchórzno na Pojezierzu Myśliborskim. [Die Vegetation auf Seekreidelager am Ufer des Tchórzyno-See]. Fragm. Flor. Geobot. 6 (4): 561-572. (in Polish with German summary)

JASNOWSKI M., JASNOWSKA J., MARKOWSKI S., RADOMSKI J. 1972. Warunki siedliskowe i szata roślinna torfowiska nakredowego w rezerwacie Tchórzyno na Pojezierzu Myśliborskim. [Habitat Conditions and Vegetation of the Peat Bog on Chalk Substratum in the Reserve Tchórzyno in the Myślibórz Lake Region]. Ochr. Przyr. 37: 157-232. (in Polish with English summary)

KACZMAREK C. 1963. Rozmieszczenie wapniolubnej roślinności łąkowo-bagiennej na Pojezierzu Leszczyńskim. [La Distribution de la Vegetation Calciphile sur les Prairies Palustres au pays Lacustre de Leszno]. Bad. Fizjogr. nad Polską Zach. 12: 213-225. (in Polish with French summary)

KĘPCZYŃSKI K., CEYNOWA M. 1968. Zespół kłoci wiechowatej Cladietum marisci (All. 1922) Zobrist. 1935 na obszarze Borów Tucholskich. [Cladietum marisci - Ass. (All. 1922) Zobrist. 1935 auf dem Tuchola-Heidegebiet]. Zesz. Nauk. UMK Ser. Biol. 11 (21): 41-48. (in Polish with German summary)

KŁOSOWSKI S. 1986-1987. Cladietum marisci (All. 1922) Zobrist 1935 w północno-wschodniej Polsce na tle warunków siedliskowych. [Das Cladietum marisci (All. 1922) Zobrist 1935 im nord-östlichen Teil Polens und seine Standortverhältnisse]. Fragm. Flor. Geobot. 31-32 (1-2): 207-223. (in Polish with German summary)

KŁOSOWSKI S. 1990. Litoralvegetation Stehender GewässerÖkologie, Dynamik and Bioindikationswert. Polish Bot. Stud. 1: $149-184$

KŁOSOWSKI S., TOMASZEWICZ H. 1979. Rzadkie i interesujące rośliny z Pojezierza Suwalskiego. [Seltene und interessierte Pflanzenarten aus der Suwałki-Seenplatte]. Fragm. Flor. Geobot. 25 (3): 371-375. (in Polish with German summary)

MATUSZKIEWICZ W. 2001. Przewodnik do oznaczania zbiorowisk roślinnych Polski. PWN, Warszawa, pp. 537. (in Polish)

MIKULSKI J.S. 1982. Biologia wód śródlądowych. PWN, Warszawa, pp. 491. (in Polish)

NAMURA-OCHALSKA A. 2004. Nowe, godne ochrony stanowisko Cladium mariscus (Cyperaceae) w północno-wschodniej Polsce. [A new station of Cladium mariscus (Cyperaceae) worthy of protection in north-west Poland]. Fragm. Flor. Geobot. Polonica 11: 6-10. (in Polish with English summary)

PENZIO K.J., MILLER S.J., LEE M.A. 1995. Germination of sawgrass, Cladium jamaicense Crantz, under vatying hydrologic conditions. Aquat. Bot. 51: 115-120.
PODBIELKOWSKI Z., TOMASZEWICZ H. 1996. Zarys hydobotaniki. PWN, Warszawa, pp. 531. (in Polish)

POLAKOWSKI B. 1963. Stosunki geobotaniczne Pomorza Wschodniego. [Geobotaniceskije sootnoscenija vostocnovo primorja]. [Die Geobotanischen Verhäeltnisse im Oestlichen Pomorze]. Zesz. Nauk. WSR. Olsztyn, 15 (1): 1-167. (in Polish with Russian and German summary)

POLAKOWSKI B. 1969. Zespół Cladietum marisci (All. 1922) Zobrist 1935 w północno-wschodniej Polsce. [Das Cladietum marisci (All. 1922) Zobrist 1935 in Nordostpolen]. Fragm. Flor. Geobot. 15 (1): 85-90. (in Polish with German summary)

SCHMID B., BAZZAZ F.A. 1987. Clonal integration and population structure in perennials: effects of severing rhizome connections. Ecology, 68: 2016-2022.

SCHMID B., HARPER J.L. 1985. Clonal growth in grassland perennials. II. Growth form and fine-scale colonizing ability. J. Ecol., 73: 809-818.

SILVERTOWN J.W. 1987. Introduction to Plant Polulation Ecology. Longman Scientific and Technical, Barking, UK.

SOLINSKA B. 1965. Cladietum marisci am Lisunie-See im nördlichen Teil der Pisz-Heide. Mater. Zakł. Fitosoc. Stos. UW. 6: 121-128.

SPELLERBERG J.F., HARDES S. 1992. Biological conservation. Cambridge University. Press, New York, Port Chester, Melbourne, Sydney.

STANIEWSKA-ZĄTEK W. 1977. Zespół Cladietum marisci All. 1922 w Wielkopolsce. [Cladietum marisci All. 1922 in Wielkopolska.] Bad. Fizjogr. nad Polską Zach. 30: 69-82 (in Polish with English summary)

SYMONIDES E. 1989. Bank nasion jako element strategii reprodukcyjnej terofitów. [Seed bank as an element of annual reproductive strategy]. Wiad. Ekol. 25 (2): 107-144. (in Polish with English summary)

TILMAN D. 1987. On the meaning of competition and the mechanisms of competitive superiority. Funct Ecol 1: 304-315

TILMAN D. 1988. Plant strategies and the dynamics and structure of plant communities. Princeton University Press, Princeton, New Jersey.

TOBOLSKI K. 1987. Holocene vegetational development based on the Kluki reference side in the Gardno-Łeba Plain. Acta Paleobot., 27, 1: 179-222.

TOBOLSKI K. 2000. Przewodnik do oznaczania torfów i osadów jeziornych. Vademecum geobotanicum. PWN, Warszawa. pp. 508. (in Polish)

VASANDER H., LINDHOLM T., KAIPIAINEN H. 1988. Vegetation patterns drained and fertilized raised bog in southern Finland. Proc. The Int. Peat Congress, USSR, Leningrad.

WEINER J. 1999. Życie i ewolucja biosfery. PWN. Warszawa, pp. 592. (in Polish)

ŻUKOWSKI W., JACKOWIAK B. 1995. Ginące i zagrożone rośliny naczyniowe Pomorza Zachodniego i Wielkopolski. [Endangered and threatened vascular plants of Western Pomerania and Wielkopolska]. Prace Zakł. Taksonomii Un. Mickiewicza w Poznaniu. Bogucki Wyd. Nauk. Poznań, pp. 145. (in Polish and English) 